\title{
INCLUSIVE EDUCATION IN THE ILLUSIO SPACE. A PROPOSAL TO RESEARCH THE SCHOOL FIELD
}

\author{
KAROLINA KOŁODZIEJCZAK
}

\begin{abstract}
This article describes planned research on the practice of inclusive education in Poland in the context of Pierre Bourdieu's [3] concept of society, in which field is one of the basic concepts. In using this term, the author intends to describe the social space of the school, the social space's organization, and the state of the school's social position; as well as to answer the question: What is the reality of inclusive education, as analyzed using the illusio category? It is necessary to analyze the state of the implementation of the assumptions made by inclusive education in primary schools, and to find out the opinions of teachers working with students covered by this type of education. In P. Bourdieu's [3] concept of society, the field is the source of what is social, it shapes it in those who are within its area of influence. This "attitude" is called illusio [11, p. 188]. Illusio is a state of engrossment in a game that the participant is unaware of. This is the result of direct recognition of the field's requirements. Everyday educational life in the context of P. Bourdieu's concept falls within the field of activities of the Ministry of National Education. The teacher takes part in a game whose rules are set by the Ministry of National Education. In the context of the proposed research within the scope of the field, apart from teachers, there are also the parents of the children covered by inclusive education.
\end{abstract}

Keywords: inclusive education, Pierre Bourdieu, illusio, social field.

\section{INTRODUCTION}

In recent decades, a feature of educational research has been the increased interest in the issue of educating people with disabilities. Inclusive education, despite the fact that it has been an area of interest for researchers and people involved in education for a long time, is still a relatively unknown subject. Due to the constant changes taking place in the field under discussion, this area should be constantly analyzed and described. It is a specific social space in which teachers and students are located on a daily basis, and among these students are also those who have special educational needs. This education is integrally connected with universal education at the level of the education system's ideological assumptions, and the ways in which they are achieved. As teaching practice shows, noble ideas are not always reflected in educational practice [10]. This article is an attempt to create a theoretical framework for research on inclusive education based on Pierre Bourdieu's field theory.

The scientific objective of the described project is to examine the assumptions of inclusive education in its hidden dimension, together with declarations obtained from subjects, and the confrontation between theory and practice; as well as to analyze the presence of the category of appearances in this type of education in a critical way. The features of the studied phenomenon will be presented, and a 
critical analysis of the functioning of inclusive classes in the area of school education carried out; this will result in a description of the reality, and the mechanisms present in inclusive education. It is important to examine the place that parents, guardians, and teachers (of children included in integration) assign to it in the system of goals and developmental needs, and to determine the optimal pedagogical activities in this area.

\section{RESULTS AND DISCUSSION}

\subsection{INCLUSIVE EDUCATION - ASSUMPTIONS}

The term "inclusive education/integration" refers to a combination of two realms of reality that had previously functioned relatively independently. As a result of this combination, a new form of social practice was created $[19$, p. 9]. The study of this practice has required new theoretical concepts that go beyond the conceptual framework and conceptualization of reality. The concept, implementation, and assumptions of school integration have undergone conceptual changes over the years and have been determined by the vision for the development of education for children with disabilities. In special education, there have been changes that make it possible to go beyond common knowledge, including that of integration. It is not about the concept of integration itself, or, in the simplified version, inclusion, but about the process and even the current and specific view of reality. In this sense, the integration paradigm means the dissemination of consent for the coexistence of disabled and nondisabled people [12, p. 154]. An inclusive education system is based on the fullest possible inclusion, in ordinary schools and other educational institutions, of children with disabilities, while taking into account their different needs. This system has been an attempt to answer the increasingly often articulated slogans concerning the special educational needs of people with various types of disabilities. By design, inclusive education covers individuals with all types of disabilities. Its basic assumption is the necessity for creating conditions for disabled people to be able to grow and gain knowledge in a natural environment among able-bodied peers, as well as to shape positive psychosocial ties between disabled and non-disabled peers [23, p. 16-17]. Inclusive schools are, by definition, community schools, which aim to involve parents in the work of education, and bring the local community closer.

A. Hulek [7, p. 495], in justifying the sense of building an inclusive education system for people with disabilities, writes that "the most advantageous system is a system of education and upbringing of children and adolescents who have deviations from the norm, which allows the various work of pupils to be satisfied". The author argues this by pointing to the value of this form of education, because "it is of particular importance in shaping mutual attitudes, and personal and social culture" [7 p. 495]. Of course, the idea of integration does not come about through the formal combining of the abled and the disabled. The main issue here is social integration. In the local community, the integration of disabled people takes place on three mutually dependent levels: psychological, pedagogical, and sociological.

In order for people to be able to pursue their dreams and passions, and to develop themselves and their potential, education needs to be an integral part of the process, in addition to many other factors. It is, therefore, very important that the educational system in Poland takes into account disabled children and includes them in compulsory education from an early age. One of the best ways of not excluding people with disabilities is inclusive education, which takes place when children with disabilities are educated in publicly accessible educational institutions, where various aids to improve their functioning and learning are used.

Thanks to an analysis of the literature relevant to research results on the process of students' integration into school, it can be noted that integration is still imperfect and not fully described scientifically, this requires hard and persistent work. The conclusions drawn from educational experience and practice have had a significant influence on the modification, enrichment, and improvement of inclusive forms of education for the disabled. And the experience of inclusive teaching has contributed to a change in the view that special schools should be places of education for disabled 
children. Even though researchers are eager to engage in this inclusive movement, so far, research on inclusive school has been fragmentary. The research area is, especially, the consequence of resultsfocused study rather than studying the actual process of integration at the school level. Integration research is diverse and covers a broad area, with the most important studies including the assessment of teaching achievements, and social and emotional functioning. Many psychologists and educators have conducted research on inclusive school [6], [21], [26]. Foreign research focused on inclusive education is also interesting [15], [16], [17], [18], [20], [24]. The premise of inclusive education is to create conditions for students that will be most beneficial for them. These issues are becoming of increasing interest in Poland [22]. The main goal of the research is most often to determine the attitude of teaching staff and parents towards integration in a regular school. However, little is known about the actual activities that take place within education: to what degree the integration postulates are in line with the needs of contemporary recipients, and whether these assumptions have foundations. The planned research makes it possible to explore a new research field: the area of integrated education. This type of research has not yet been undertaken and has important cognitive meaning.

The aim of the research designed by the author is to examine the assumptions of integrated education in its hidden dimension, together with declarations obtained from subjects, and the confrontation between theory and practice; as well as to analyze the presence of the category of appearances in this type of education in a critical way. The assumptions of integrated education and their actual implementation as stated in the declarations of the students' parents and the teachers from these schools will be subject to critical analysis. The research will be positioned in the interpretative paradigm. The results can be used in educational practice, and thanks to a critical analysis of integrated education's assumptions and their actual implementation, may be useful in creating recommendations for schools and school board projects.

It seems important to address the following issues, which require in-depth analysis:

- What is the game ${ }^{1}$ of inclusive education?

- What rules and laws are applied to the game by the authorities, teachers, parents, and students?

- What are the positions of the subjects in the game: authorities, teachers, parents, students?

- What axiological mechanisms and compulsory enforcement of non-life regulations (both pragmatic and organizational) are visible at the sources of illusio in inclusive education?

- What meanings do the entities - authorities, teachers, parents, students - give to inclusive education and its elements (e.g. what meanings do they give to learning objectives, methods, content)?

The aim of the research is to critically analyze the functioning of integrated classes in the area of school education, which will result in describing the reality and mechanisms present in integrated education. This will provide an opportunity to acquire knowledge that is important in the area of social sciences, such as, acquiring knowledge that will enable practitioners to undertake such activities where the assumptions of inclusive education and activity correspond as much as possible to the school reality. The practical application of these results is associated with the possibility of expanding cooperation between the school, teachers, and parents, and providing students with the most favorable conditions for development within educational institutions. It is necessary to analyze the state of implementation of the assumptions of inclusive education in primary schools, to examine the degree to which apparent actions represent real actions, and to find out what the opinions of parents and people working with students covered by this education are. It is important to examine the place that parents, guardians, and teachers of children (included in integration) assign to it within the system of goals and developmental needs, and to determine the optimal pedagogical activities in this area.

\footnotetext{
1 The term "game", in this context, refers to P. Bourdieu's field theory. Each field has its own rules and set of rational demands on its participants (players). It shapes those who enter its area. People in it are engrossed in the game. See: Bourdieu P., Rozum praktyczny. O teorii działania, przeł. J. Stryjczyk, Kraków 2009.
} 
Due to the specific nature of the research, no research hypotheses have been formulated in the project. The premise of the pre-research work is that the assumptions of integrated education in primary schools only appear to have been implemented, the school lives a double life, there is a game of appearances and fiction, and the implementation of the idea of integration is illusory. This kind of assumption results from the experiences of the project's author, who works for one of Krakow's primary schools that has some inclusive education, hence the adoption of a critical perspective and an interpretative paradigm.

\subsection{INCLUSIVE EdUCATION IN PIERRE BOURDIEU'S FIELD OF THE SPACE}

Looking at inclusive education from the perspective of entering the school field is particularly related to paying attention to the external factors that constitute this form of education, as well as the circumstances that accompany the subjects of this educational scene. This article is largely devoted to a description of the research that the author intends to carry out in inclusive schools in order to find out the opinions of teachers working in them, and to look at inclusive education from the inside, through the eyes of the respondents. Therefore, it seems particularly useful to base the obtained results on Pierre Bourdieu's theory. Pierre Bourdieu's sociological theory and the conceptual framework created by the author seem to be adequate in the context of analyzing the area of inclusive education. The subjects of the educational scene of inclusive education, which are the teachers working in this type of school, who belong to society and are subject to its laws, take part in the game. Their place is related to the functioning of the field. In light of Bourdieu's theory, all persons in the field have habitus. This, in turn, is the principles instilled and internalized in the course of socialization, the mental structures that allow them to create and organize specific practices and to recognize and understand the reality around them and act on it [25, p. 42]. Therefore, as S. Krzychała and B. Zamorska write, teachers have previous social experiences that allow them to find themselves in the educational system, making it easier to identify with the logic of the school field [13, p. 31]. This paper applies to teachers of all levels of education, as well as types and forms of education. Each teacher has one's own past experiences, which, to a greater or lesser extent, affect their perception of the field and attitude towards it.

One of the basic categories in the analysis is habitus. This term appeared during conversations with teachers working in inclusive schools and is related to the interlocutors' reflections on professional experience. It is shown as a certain cognitive schema, a model, which, for a human being, plays the specific role of a tool that organizes all the processes for perceiving reality. The result of which is the creation of a subjective image of the world: people, things, and events in the human mind. At the same time, it is a source of practices that appear in a given field. Habitus turns out to be the principle of perceiving and evaluating these experiences. The research concept of this work is embedded in Pierre Bourdieu's sociological theory. Playing, according to Bourdieu, is a metaphor for social life. This appears to be relevant and significant in sociology for several reasons. M. Jacyno [8, p. 17], listing these reasons, writes about the significant ambiguity of the concept of the game. The author of the theory does not give the reader a specific answer as to what the game is about, what the game is, the degree of its brutality, or on what terms it is played. "Apart from comparisons to a race, a fight against time, where the pace of the fight and the reflexes of the participants are decisive, there is often a competition comparable only to the fight for life and survival" [8, p. 17]. Habitus is the result of the work of assimilation and inculcation, which is necessary for objective structures and the products of collective history to be reproduced in the form of adapted and permanent dispositions, which is the condition of their functioning [5, p. 77]. A specific example of a relatively independent subsystem in the social world is the education system. Therefore, this relative autonomy is a fundamental element that justifies the notion of a field, which is created in opposition to a Marxist analysis that adjusts all social orders to fit into the category of class struggle [14, p. 3]. It therefore seems particularly important and justified to embed the theoretical framework for inclusive education research within P. Bourdieu's theory.

People are embedded in a social space that, according to the author, reveals a tendency to create and establish some kind of social order, as well as to reproduce it. The pattern of this space is shaped by individuals who, with the help of specific conditions related to the position they occupy in the field, 
implant specific cognitive structures in them, i.e., habitus. It can be said that in the area of the social field there is a kind of game, or even a dispute, about the possibility of pushing through one's vision, rules of division, or view [1, p. 142].

A. Kłoskowska writes that the habitus is "a complex of interiorization, that is, tendencies, attitudes, dispositions internalized, introduced into the sphere of human habits. Habitus extends to the field of evaluating emotional reactions and attitudes towards values. It is precisely the result of [the] subjectivization of objectivity, expressed in an objective way again" [9, p. 9].

In describing the habitus, the author claims that,

The imprint of the "rules of the game" is so strong that it is imperceptible as an externally imposed factor, and so effective that it ensures an almost automatic adaptation to the situation identified as the situation covered by the rules. (...) The power and depth of internalization give them a quasi-instinctive character. (...) The concept of habitus is to exclude the problem of conscious or unconscious action, causality or teleology. Habitus is the internalization of "objective necessity which makes a virtue." This results in the use of strategies that are objectively adapted to the situation. This gives the action the appearance of rationality. [9, p. 14-15]

P. Bourdieu also wrote about symbolic violence in the context of national cultures in connection with the change in which actors become dominant and their relations in the culture, but these are only passing references. A more important place in the author's considerations is the issue of the first, initial stage of pedagogical work, which is the unconditional beginning of inculcating culture [2, p. 21]. This process takes place in small primary groups, the family or the origin's local environment. Bourdieu concludes by claiming that under the influence of primary authority and initial pedagogical activity, a basic habitus is formed, which is less "reversible than all the subsequent effects of subsequent phases of pedagogical work" [2, p. 21]. This primordial habitus is at the core of all subsequent habitus formation and cultural assimilation. Habitus is jointly responsible for creating the rules of the game in a given field, as well as the course of relations that take place there. They also shape the interests of the actors, their preferences, and, in part, their capital resources. The desideration of success in a particular field is the maximum compatibility between the requirements of the field and the structures of the habitus. It enables the maximum understanding of the nature of the field and its structure, in a way that prompts or dictating the choice of appropriate strategies based on an adequate perception of opportunities and threats.

In P. Bourdieu's theory, social space is constantly branched, which results in the creation of new social fields that can be perceived as institutionalized arenas. A social conflict takes place in their area, a game or a struggle to control given forms of capital, a change or maintenance of position within the social space, or even a change or maintenance of the rules of the game itself. This can be understood as a kind of struggle for power.

In analytical terms, a field can be defined as a network or configuration of objective relationships between items. Positions are objectively defined due to their existence and due to the conditions they impose on people or institutions occupying them, defining their current and potential situations (situs) in the distribution structure of various types of power (or capital). In turn having this power (capital) determines access to specific benefits, which are played for in a given field. (...) The field is an area of power relations, and not only of meanings and struggles aimed at their transformation, and, consequently, of permanent change. [4, p. 78]

The analysis of the area of the field proposed by the author takes place in three stages. Firstly, one has to estimate the position of a given field in relation to the field of power; second, it is necessary to describe the objective structure of the relationships between the positions that people and institutions occupy, and whether and how they compete with each other in this field; and the third is to analyze the habitus of the subjects and examine the systems of dispositions they acquire during the internalization of a given type of social or economic condition, the dispositions being the result of, more or less, favorable conditions that emerge while traveling a given path in the field [4, p. 87].

A question arises as to whether the regulations, laws, and assumptions of inclusive education completely correspond to the educational reality. Are the parents of children attending schools with 
inclusive classes, and the teachers who teach in these schools, satisfied with the changes taking place, and with the implementation of clearly defined assumptions? At this point, it is worth referring to the concept of society by P. Bourdieu [3] in which one of the basic concepts is the field. Using this term, he describes the global social space, its organization, and the state of the social positions. The field is the source of what is social. "Each field is an institutionalization of the point of view embedded in things and habitus" [1, p. 142]. The field shapes those who enter its area of influence; this "attitude" is called illusio [11, p. 188]. Illusio is an unconscious state of being absorbed in the game. This is the result of the direct recognition of the field's requirements. Understanding the rules and skills of the game, as well as joining in, itself occurs without knowing it. The requirements are obvious and they become illusio, i.e., the condition for participation in the game. For people who do not participate in this game, illusio and its rules are fiction, something incomprehensible. Believing in the validity and truthfulness of certain realities, and taking fiction for reality, is an illusion. People who are not in the field may see some actions and rules of the field. Every day, educational life in the context of P. Bourdieu's concept comes within the field of activities of the Ministry of National Education. Like every social field, it is governed by its own rules and laws, which define the actions of the individuals involved. By the field's participants, the rules are considered essential and are respected. The teacher takes part in a game whose rules are set by the Ministry of National Education. As a participant in a forced game, he or she may, or should, fully respect the regulations, laws, and other guidelines, and treat them as fully acceptable. The Ministry expects them to operate in the illusio space, whose clear rules are dictated by routine activities [8]. In the context of the proposed research within the scope of the field, apart from teachers, there are also the parents of children covered by inclusive education. This is an innovative approach to the subject.

Inclusive education is a form of institutional learning and, as Bourdieu writes:

Each institutionalized education system (ES) owes specific features of its structure and functioning to the fact that it should create and recreate - thanks to the institution's own resources - institutional conditions, the existence and duration of which (institution's self-reproduction) are necessary both for its own implementation function and to fulfill its function of recreating cultural arbitrariness, the reproduction of which contributes to the reconstruction of relations between groups or classes (social reproduction). [2, p. 112]

The above fragment from Reproduction, in writing about the education system in the context of pedagogical activities, perfectly correlates with the social field, which is the area of integrated education. Thanks to the agency of teachers, this area generates the conditions necessary for it to continue to exist. By adapting to the requirements of the field, the structures and relationships that prevail in the field are maintained.

When writing about inclusive education in the context of Pierre Bourdieu's theory, it is impossible not to mention that this area of education is a certain form of activity area in which a network of relationships is created. These are various types of contacts between the entities of the educational scene in inclusive education. People who participate in this field take part in a game in which certain benefits are at stake. According to Bourdieu, each field imposes certain forms or specific strategies of action on the actors. The school, including the inclusive school, is a specific example of a place where this practice is also visible. The specificity of its organization contributes to the reproduction and dissemination of cultural capital, the consequence of which is the constant duplication and reconstruction of the structures of social space [5, p. 29-32]. In line with this theory, one should mention the concept developed by the author, namely capital. Capital is considered to be a type of resource that allows the participants of the game to obtain certain benefits or advantages. The author lists various types of capital: economic, social, cultural, symbolic. In the context of this analysis of capital, it is possible to define the psychophysical abilities of the student and their potential. Inclusive education, as a field, predisposes you to be an arena in which the actors participating in this symbolic game come from various backgrounds, having various capital at their disposal. It can be said that the game played in this field has high stakes; especially for students covered by integration, for whom it may be taking a specific position in class structure and even success in the future. However, the teachers and all those 
working in inclusive schools are also in a specific place. People who have more capital at any given time will achieve higher positions in the hierarchy of the game, especially if they learn to navigate in an area of culture that is legitimate.

\section{CONCLUSIONS}

Inclusive education takes place when children with disabilities learn in generally accessible institutions using auxiliary resources that improve their functioning and learning. In the field of children's upbringing and education, it is visible in the increasing abandonment of segregated forms of education and the introduction of integrated forms. Therefore, further research and reflection on this type of education is extremely important in terms of education. In connection with the visible cognitive gap, it seems educational, and also necessary, to construct research aimed at presenting the space of integration schools as being one of the forms of social space, and discovering the types of game, the rules prevailing in it, and rules that govern this type of education. The project takes up the issues concerned with a new and poorly recognized problem area, and makes inclusive education the subject of the analysis in the context of Pierre Bourdieu's [3] field theory. This supplements the current state of knowledge about the analysis of inclusive education in illusio space, a thus far overlooked perspective of the parents and teachers of children covered by this form of education. The project initiates a new approach to the analysis of the issues raised. In the theoretical dimension, the project supports the development of knowledge about the area of the research, such as issues of inclusive education from the perspective of the educational scene's entities, like teachers and parents of children covered by inclusive education, while taking into account the multidimensionality of this phenomenon. The results of the project, in the form of empirically grounded theses concerning the perception of inclusive education, may also contribute to a revision of the existing concepts of special education and school pedagogy. This will provide an opportunity to obtain knowledge that is important in the area of social sciences, for example, knowledge that will enable pedagogue practitioners to undertake actions so that the assumptions of inclusive education and activities correspond to the school reality as much as possible. The practical application of these results may contribute to the expansion of cooperation between the school, teachers, and parents, and provide students with the most favorable conditions for development in educational institutions.

\section{REFERENCES}

[1] Bourdieu P. Pascalian Meditations. Warsaw 2006. (in Polish)

[2] Bourdieu P., Passeron J.C. Reproduction. Elements of teaching the theory of the teaching system. Warsaw, 1990. (in Polish)

[3] Bourdieu P. Practical reason. On The Theory of Action. Krakow, 2009. (in Polish)

[4] Bourdieu P. Invitation to reflective sociology. Warsaw, 2001. (in Polish)

[5] Bourdieu P. The Practical Sense. Krakow, 2008. (in Polish)

[6] Gajdzica Z. Principles of the organization of education in inclusive education of students with disabilities. Disability, 33 (2019). (in Polish)

[7] Hulek A. Integration system of special education. In: Hulek A. (Ed.) Rewalidation pedagogy. Warsaw, 1977. (in Polish)

[8] Jacyno M. Illusions of everyday life. On Pierre Bourdieu's sociological theory. Warsaw, 1997. (in Polish)

[9] Kłoskowska A. Pierre Bourdieu's sociological theory. Introduction to the Polish edition. In: Bourdieu P., Passeron J. C. Reproduction. Elements of teaching the theory of the teaching system. Warsaw, 1990. (in Polish)

[10] Kołodziejczak K., Smoter K. Integrated Education in Poland - Between the Explicit "Legal" / Legitimate and "Apparent" Dimension. Journal of Vasyl Stefanyk Precarpathian National University, 6 (1) (2019). 
[11] Knasiecka - Falbierska K. A teacher in illusio space. In: Dudzikowa M., Knasiecka - Falbierska K. (Eds.) Perpetrators and / or victims of sham activities in school education. Kraków, 2013. (in Polish)

[12] Krause A. Contemporary paradigms of special education. Kraków, 2010. (in Polish)

[13] Krzychała S., Zamorska B. Teachers in the face of foreign education - reconstruction of collective patterns of orientation. In: Kwiecińska R., Szymański M.J. A teacher in the face of social differences. Krakow 2010. (in Polish)

[14] Lebaron F. Comments on the theoretical and methodological aspects of the notion of field. Studia Litteraria et Historica, 6 (2017). (in Polish)

[15] Lindsay G. Educational psychology and the effectiveness of inclusive education / mainstreaming. British Journal of Educational Psychology, (2007).

[16] Mitchell D. What Really Works in Special and Inclusive Education. Using Evidence-Based Teaching Strategies. Routledge, London, 2007. doi: 10.4324/9780203105313

[17] Noelle V. Students See School Differently: An Empirical Study of School Concepts by Students and Their Consensus. Peter Lang Verlag, Frankfurt am Main - Berlin - Bern - New York - Paris - Vienna, 1995. (in German)

[18] O'Hanlon Ch. Inclusive Education in Europe. Routledge, London, 1995.

[19] Pachociński R. Contemporary educational systems. Warsaw 2000. (in Polish)

[20] Page A., Boyle Ch., McKay K., Mavropoulou S. Teacher perceptions of inclusive education in the Cook Island. Asia - Pacific Journal of Teacher Education, 47 (2019).

[21] Plichta P., Olempska-Wysocka M. Exposure to peer aggression of disabled students of inclusive schools in the reports of supporting teachers. Educational Studies, 28 (2013). (in Polish)

[22] Sack B., Stanek A. Integration of students with disabilities in mass schools. Educational discourses, 2001. (in Polish)

[23] Stankowski A., Stankowska A. Integration - idea and reality. In: Stankowski A., Baluszkiewicz M. (Eds.) On the difficult art of being together, or the different faces of integration. Kraków, 2006. (in Polish)

[24] Thomas G., Vaughan M. Inclusive Education: Readings and Reflections. Open University Press, 2004.

[25] Zalewska - Bujak M. Teacher in the school field - in the light of Pierre Bourdieu's theory and teaching narratives. Katowice, 2017. (in Polish)

[26] Zamkowska A. Parents' attitudes towards inclusive education in international research. Disability, 33 (2019). (in Polish)

Address: Karolina Kołodziejczak, Institute of Pedagogy of the Jagiellonian University, 12 Batorego St., Kraków 31-135, Poland.

E-mail: karolina.kolodziejczak@doctoral.uj.edu.pl.

Received: 5.02.2021; revised: 18.03.2021.

Колодзейчак Кароліна. Інклюзивна освіта в ілюзійному просторі: пропозиція дослідження шкільного середовища. Журнал Прикарпатського університету імені Василя Стефаника, 8 (1) (2021), 132-140.

У статті описано здійснене дослідження у практиці інклюзивної освіти в Польщі в контексті концепції суспільства П'єра Бурдьє, де сфера є однією з основних концепцій. Використовуючи цей термін, автор має намір описати соціальний простір школи, організацію соціального простору та стан соціального становища школи; а також відповісти на запитання: Якою є реальність інклюзивної освіти, проаналізованої через призму категорії illusio? Вадливим для автора було проаналізувати стан реалізації припущень, зроблених інклюзивною освітою в початкових школах, та з'ясувати думки вчителів, які працюють з учнями, охопленими цим видом освіти. У концепції суспідьства П. Бурдье 
сфера є джерелом соціальним, вона впливає на тих, хто знаходиться у зоні його впливу. Таке "ставлення" називається illusio [11, с. 188]. Illusio - це стан захоплення грою, про який учасник не знає. Повсякденне освітне життя в контексті концепції П. Бурдьє потрапляє у сферу діяльності Міністерства національної освіти. Вчитель бере участь у грі, правила якої встановлює Міністерство національної освіти. У контексті пропонованого дослідження, крім вчителів, важливу роль відіграють також батьки дітей, охоплених інклюзивною освітою.

Ключові слова: інклюзивна освіта, П’єр Бурдьє, ілюзія, соціальна сфера. 